\title{
Necrotizing granulomatous meningoencephalitis due to Balamuthia in an immunocompetent child
}

\section{Figure 1 Brain imaging (CT and MRI) showing mass lesion}
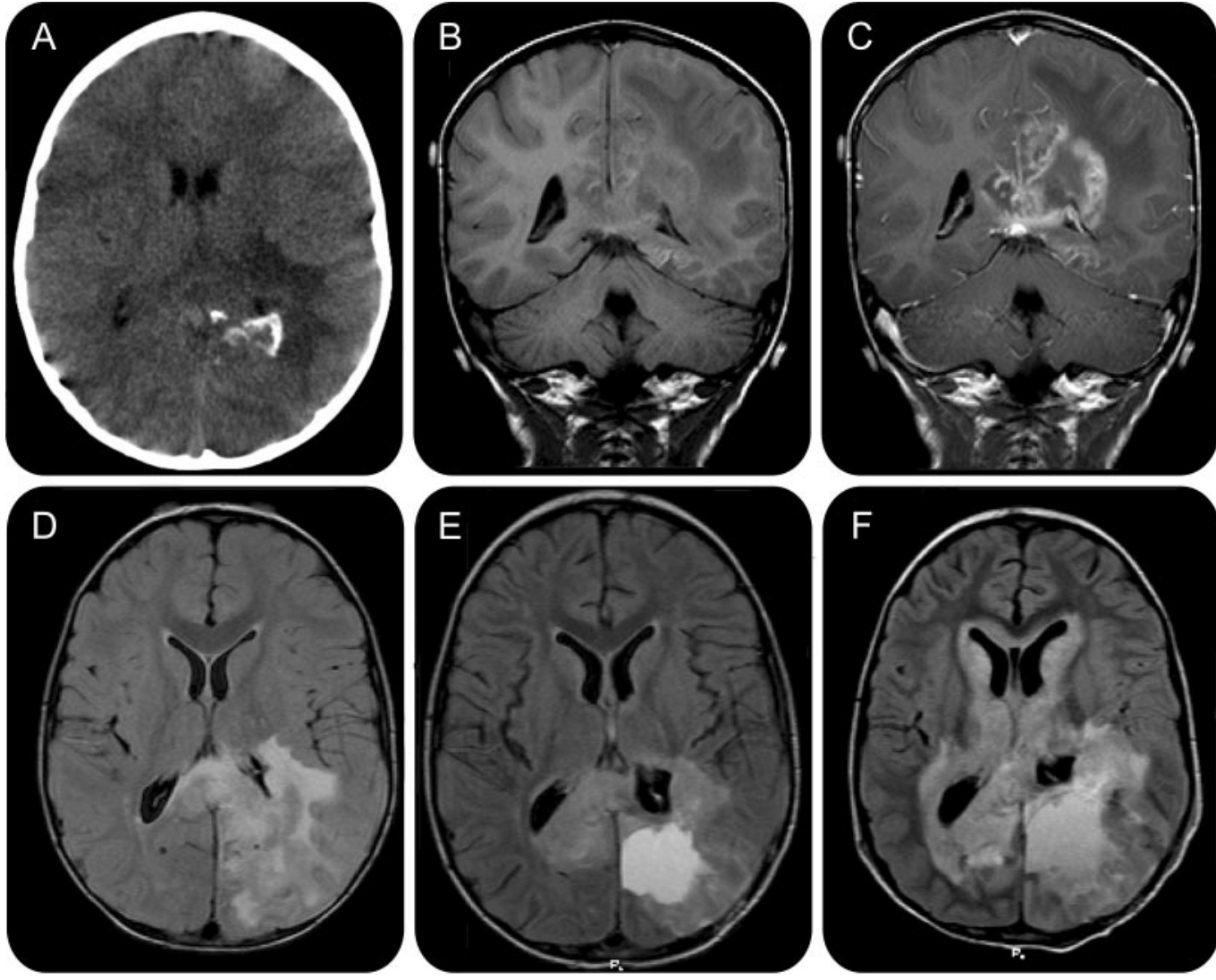

(A) Partially calcified mass on CT. (B, C) Pregadolinium and postgadolinium T1-weighted coronal MRI with irregular peripherally enhancing lesion. (D-F) Axial fluid-attenuated inversion recovery images showing serial progression (preoperative and postoperative).

A 4-year-old boy presented with headache for 2 months. Neuroimaging revealed a partially calcified left parieto-occipital lesion suspicious for tumor (figure 1, A-C); biopsy showed necrotizing granulomatous meningoencephalitis. Postoperative MRI showed rapid progression (figure 1, D-F). He developed fever and seizures and died within 3 weeks despite IV vancomycin, ceftazidime, metronidazole, amphotericin, and fluconazole. Autopsy revealed Balamuthia mandrillaris (figure 2). This free-living ameba causes granulomatous encephalitis in immunocompromised and immunocompetent hosts (as was our patient), ${ }^{1}$ mimicking tumor and acute disseminated encephalomyelitis. It is usually fatal, without definitive therapy. Clinical presentation and imaging are nonspecific, making antemortem diagnosis challenging. ${ }^{2}$

\section{P.S. Ghosh, MD, D. Ghosh, MD, Cleveland, OH; T. Loddenkemper, MD, Boston, MA; R.A. Prayson, MD, T. Tekautz, MD, Cleveland, OH; C.S. Sriram, MD, Rochester, MN; L. Danziger-Isakov, MD, Cleveland, OH}

Author contributions: Dr. P.S. Ghosh: drafting/revising the manuscript, acquisition of data. Dr. D. Ghosh: drafting/revising the manuscript, study concept or design. Dr. Loddenkemper: drafting/revising the manuscript, study concept or design, acquisition of data. Dr. Prayson: drafting/revising the manuscript, analysis or interpretation of data, acquisition of data. Dr. Tekautz: drafting/ revising the manuscript, acquisition of data. Dr. Sriram: drafting/revising the manuscript, acquisition of data. Dr. Danziger-Isakov: drafting/revising the manuscript, study concept or design, acquisition of data. 

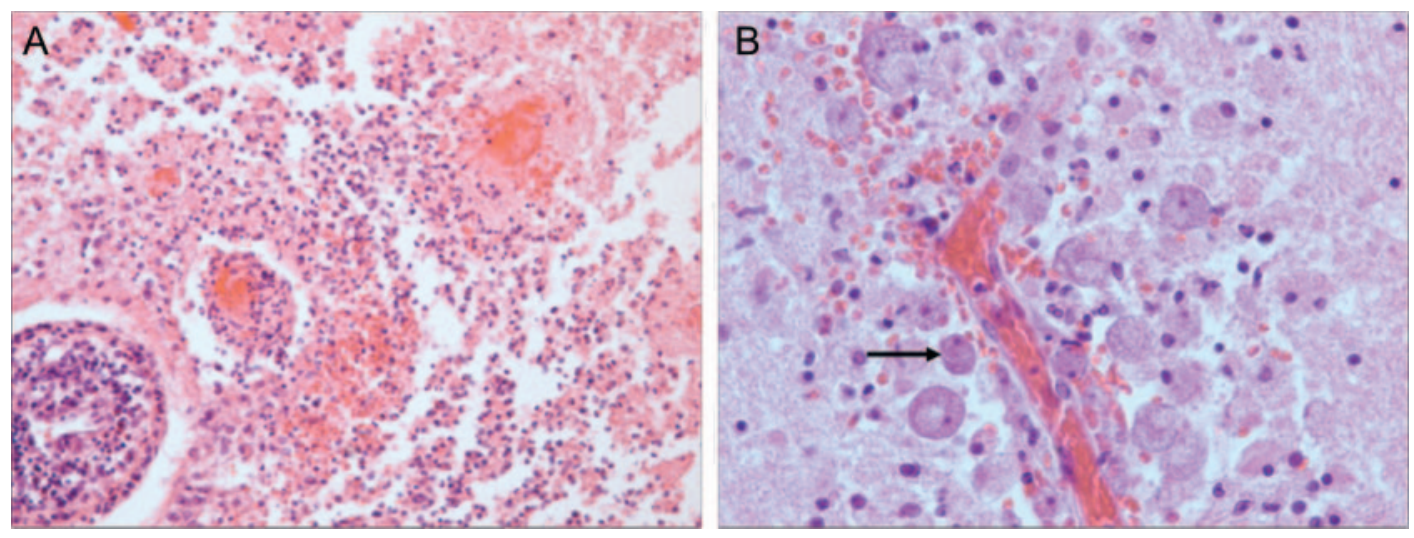

(A) Widespread encephalitis, necrosis, and angiocentric inflammation. (B) Perivascular distribution of amebic trophozoites (arrow).

Disclosure: Dr. P.S. Ghosh and Dr. D. Ghosh report no disclosures. Dr. Loddenkemper serves on the Laboratory Accreditation Board for Long Term (Epilepsy and ICU) Monitoring (ABRET), performs electrophysiologic studies at Children's Hospital Boston (20\% clinical effort) and bills for these procedures, and is funded by a Career Development Fellowship Award from Harvard Medical School and Children's Hospital Boston; and has received research support from Eisai Inc. Dr. Prayson, Dr. Tekautz, Dr. Sriram, and Dr. Danziger-Isakov report no disclosures.

Address correspondence and reprint requests to Dr. Partha S. Ghosh, Pediatric Neurology Center, 9500 Euclid Avenue, Desk S-60, Cleveland, OH 44195; ghoshp3@ccf.org

1. Combs FJ Jr, Erly WK, Valentino CM, Rance NE. Best cases from the AFIP: Balamuthia mandrillaris amebic meningoencephalitis. RadioGraphics 2011;31:31-35.

2. Siddiqui R, Khan NA. Balamuthia amoebic encephalitis: an emerging disease with fatal consequences. Microb Pathog 2008;44: 89-97.

\section{NeuroImages Are Free at www.neurology.org!}

All Neurology ${ }^{\circledR}$ NeuroImages can now be freely accessed on the Neurology Web site. See them at www.neurology.org, where you can also sign up for journal email alerts and check out other online features, including the Resident \& Fellow section, Neurology: Clinical Practice, and the weekly Neurology Podcasts. 


\section{Neurology}

\section{Necrotizing granulomatous meningoencephalitis due to Balamuthia in an immunocompetent child}

P.S. Ghosh, D. Ghosh, T. Loddenkemper, et al. Neurology 2011;77;801-802

DOI 10.1212/WNL.0b013e31822b0100

\section{This information is current as of August 22, 2011}

\section{Updated Information \& Services}

\section{References}

Subspecialty Collections

Permissions \& Licensing

Reprints including high resolution figures, can be found at: http://n.neurology.org/content/77/8/801.full

This article cites 2 articles, 0 of which you can access for free at: http://n.neurology.org/content/77/8/801.full\#ref-list-1

This article, along with others on similar topics, appears in the following collection(s):

\section{CT}

http://n.neurology.org/cgi/collection/ct

Encephalitis

http://n.neurology.org/cgi/collection/encephalitis

Meningitis

http://n.neurology.org/cgi/collection/meningitis

MRI

http://n.neurology.org/cgi/collection/mri

Parasitic infections

http://n.neurology.org/cgi/collection/parasitic_infections

Information about reproducing this article in parts (figures,tables) or in its entirety can be found online at:

http://www.neurology.org/about/about_the_journal\#permissions

Information about ordering reprints can be found online: http://n.neurology.org/subscribers/advertise

Neurology ${ }^{\circledR}$ is the official journal of the American Academy of Neurology. Published continuously since 1951, it is now a weekly with 48 issues per year. Copyright Copyright @ 2011 by AAN Enterprises, Inc.. All rights reserved. Print ISSN: 0028-3878. Online ISSN: 1526-632X.

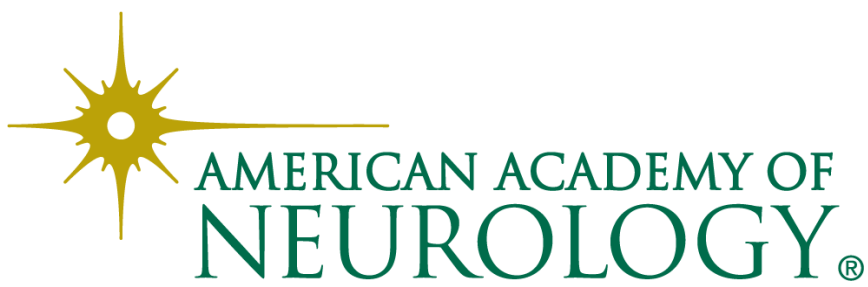

